Article

\title{
Microwave-Assisted Synthesis of
} Imidazo[4,5- $f][1,10]$ phenanthroline Derivatives as Apoptosis Inducers in Chemotherapy by Stabilizing Bcl-2 G-quadruplex DNA

\author{
$\mathrm{Li} \mathrm{Li}^{1,2,+}$, Jie-Qiong Cao ${ }^{3,+}$, Hui-Min Liu ${ }^{1}$, Qiong $\mathrm{Wu}^{3}$, Qiu-Hui Pan ${ }^{4, *}$, Zhi-Ping Zeng ${ }^{2}$, \\ Yu-Tao Lan ${ }^{5}$, Yu-Mei Li ${ }^{2}$, Wen-Jie Mei ${ }^{2, *}$, Xi-Cheng Wang ${ }^{1, *}$ and Wen-Jie Zheng ${ }^{3}$ \\ 1 The First Affiliation Hospital, Guangdong Pharmaceutical University, Guangzhou 510006, China; \\ lili7sy@163.com (L.L.); 13570250612@163.com (H.-M.L.) \\ 2 School of Pharmacy, Guangdong Pharmaceutical University, Guangzhou 510006, China; \\ 13086287838@163.com (Z.-P.Z.); 15975634468@163.com (Y.-M.L.) \\ 3 Department of Chemistry, Jinan University, Guangzhou 510006, China; caojieqiong93@163.com (J.-Q.C.); \\ wuqiongniu.1113@163.com (Q.W.); tzhwj@jnu.edu.cn (W.-J.Z.) \\ 4 Department of Laboratory Medicine, Shanghai Children's Medical Center, Shanghai Jiao Tong University \\ School of Medicine, Shanghai 200127, China \\ 5 School of Nursing, Guangdong Pharmaceutical University, Guangzhou 510006, China; \\ lanyutao@gdpu.edu.cn \\ * Correspondence: panqiuhui@263.net (Q.-H.P.); wenjiemei@126.com (W.-J.M.); \\ 13902400598@126.com (X.-C.W.); Tel.: +86-021-38625568 (Q.-H.P.); +86-020-39352122 (W.-J.M.); \\ +86-020-61321397 (X.-C.W.) \\ + These authors contributed equally to this work.
}

Academic Editor: Julio A. Seijas Vázquez

Received: 23 March 2017; Accepted: 14 May 2017; Published: 20 May 2017

\begin{abstract}
Herein, a series of imidazo[4,5- $f][1,10]$ phenanthroline derivatives RPIP (PIP $=$ imidazo $[4,5-f][1,10]$ phenanthroline, $\left.\mathrm{R}=\mathrm{NO}_{2}, \mathbf{1} ; \mathrm{CF}_{3}, 2 ; \mathrm{Cl}, 3 ; \mathrm{OH}, 4\right)$ have been synthesized in yields of $82.3-94.7 \%$ at $100{ }^{\circ} \mathrm{C}$ under the irradiation of microwave. MTT assay has been utilized to evaluate the inhibitory activity $\left(\mathrm{IC}_{50}\right)$ of these compounds against the growth of various tumor cells, and the results revealed that these compounds, especially 1, exhibited excellent inhibitory activity against the growth of A549 cells with $\mathrm{IC}_{50}$ of $15.03 \mu \mathrm{M}$. Moreover, it's also confirmed that $\mathbf{1}$ can penetrate into the membrane of tumor cells and distribute in mitochondria when observed under microscopy, resulting apoptosis of tumor cells. The further studies showed that $\mathbf{1}$ can bind to $b c l-2 \mathrm{G}$-quadruplex DNA, which demonstrated by the increase of melting point of $b c l-2$ G4 DNA in the presence of $\mathbf{1}$, as well as electronic titration and emission spectra. In a word, this kind of compound may develop as a potential apoptosis inducer in cancer chemotherapy via binding and stabilizing to the $b c l-2$ G-quadruplex DNA.
\end{abstract}

Keywords: microwave-assisted synthesis; imidazo[4,5- $f][1,10]$ phenanthroline derivatives; apoptosis inducers; $b c l$-2 G-quadruplex DNA

\section{Introduction}

1,10-Phenanthroline derivatives with an extended $\pi$-conjugated unit of fused imidazole, which can bind to duplex DNA and G-quadruplex DNA through $\pi-\pi$ stacking, exhibit great antitumor, anti-inflammatory and antiviral activity [1], as well as probes of DNA due to their strong fluorescence sensory properties towards acid [2]. Accumulated evidences show that this type of compounds exhibit promising inhibitory activity against various tumor cells. For example, it's reported 
that imidazo[4,5- $f][1,10]$ phenanthroline-dione derivatives might increase the chemosensitivity of esophageal cancer patients [3]. It's also revealed that di-substituted phenanthroline derivatives can induce apoptosis of tumor cells through binding to human telomeric G-quadruplexes DNA and inhibit the telomerase activity significantly [4,5]. In our previous work, it has been suggested that imidazo[4,5-f][1,10]phenanthroimidazole derivatives showed excellent inbitory effect against the growth of breast cancer cells and lung cancer cells through binding to G-quadruplex DNA and thus blocking the replication of DNA molecules [6,7].

The $b c l-2$ G-quadruplex DNA, a secondary structure of G-rich sequence in promoter of Bcl-2 gene via Hoogsteen hydrogen bond, is a key director to regulate the expression of $\mathrm{Bcl}-2$, which is a crucial member of the Bcl-2 family of proteins to inhibit the apoptosis and usually over-expressed in various human tumor cells [8]. More recently, a number of small molecules like pyridostatin analog [9], metal complexes [10], quindoline derivatives [11], with high affinity to $b c l-2$ G-quadruplex DNA have been reported to inhibit the transcription of Bcl-2 and thus inducing apoptosis of tumor cells. Attributed to the high ability to bind and stabilize G-qudruplex DNA, phenanthroline derivatives exhibit effectively in inducing apoptosis of various tumor cells, and it's possible that this kind of compounds may also inhibit the growth of tumor cells through interacting with $b c l-2$ G-quatruplex DNA.

In this study, a series of imidazo[4,5- $f][1,10]$ phenanthroline derivatives have been synthesized under microwave irradiation (Scheme 1). The anti-tumor activity of these compounds against the human lung adenocarcinoma A549 cells, human hepatocarcinoma SMMC7721 cells, and human colorectal carcinoma SW620 cells were evaluated by MTT assay. The results showed these compounds, especially 1 can effectively inhibit the growth of A549 cells. The further studies revealed that 1 could distribute in mitochondria of A549 cells, and thus inducing apoptosis of tumor cells through G1 phase arrest. Moreover, it was found that $\mathbf{1}$ exhibited moderate binding affinity to $b c l-2$ G-quadruplex DNA.

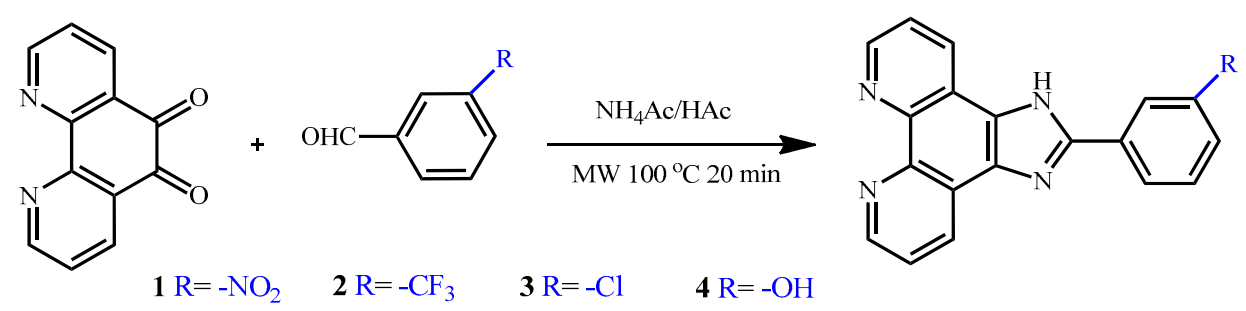

Scheme 1. Microwave-assisted synthesis route for imidazo[4,5- $f][1,10]$ phenanthroimidazole derivatives.

\section{Results and Discussion}

\subsection{Microwave-Assisted Synthesis of the Imidazo[4,5-f][1,10]phenanthroimidazole Derivatives}

Microwave-assisted synthesis technology has been widely developed in the fields of chemical synthesis, materials science, and biotechnology $[12,13]$. The technique obviously shorten reaction time, while increasing yield and product purity over traditional synthesis methods, especially in organic synthesis which typically require long hours of heating in high-boiling solvents [14]. In this study, the reaction temperature rapidly reached setting value less than $60 \mathrm{~s}$, and kept great stabilization and homogeneous of temperature and pressure in the whole heating process. As a result, the application of microwave irradiation has significantly increased the yields for most of the compounds to approximately $90 \%$ (Table 1), which was much higher than those with conventional methods [15]. 
Table 1. The yields of the target complexes by microwave-assisted synthesis method.

\begin{tabular}{cccc}
\hline \multirow{2}{*}{ Comp. } & \multicolumn{3}{c}{ Microwave-Assisted } \\
\cline { 2 - 4 } & Temperature $^{\circ} \mathbf{C}$ & Time/min & Yield $\%$ \\
\hline $\mathbf{1}$ & 100 & 20 & $91.3 \%$ \\
$\mathbf{2}$ & 100 & 20 & $82.3 \%$ \\
$\mathbf{3}$ & 100 & 20 & $94.7 \%$ \\
$\mathbf{4}$ & 100 & 20 & $89.7 \%$ \\
\hline
\end{tabular}

\subsection{Biological Activity}

The synthetic imidazo[4,5- $f][1,10]$ phenanthroimidazole derivatives can effectively inhibit the human lung adenocarcinoma A549 cells, human hepatocarcinoma SMMC7721 cells, and human colorectal carcinoma SW620 cells growth and proliferation, which were confirmed by MTT assay. Cis-platin was used as a positive control, and the inhibitory activities $\left(\mathrm{IC}_{50}\right)$ of these complexes were listed in Table 2. It was observed that these compounds displayed great growth inhibition against various tumor cells after $72 \mathrm{~h}$ treatment. It's worthy to indicate that 1 exhibited excellent inhibitory activity against $\mathrm{A} 549$ cells $\left(\mathrm{IC}_{50}=15.03 \mu \mathrm{M}\right)$ but low toxicity in normal cells. These data suggested that imidazo[4,5- $f][1,10]$ phenanthroimidazole derivatives exhibited promising inhibitory activity against the growth of tumors cells.

Table 2. The inhibitory effect $\mathrm{IC}_{50}(\mu \mathrm{M})$ of the target complexes and cis-platin on human cancer cells and normal cells at $72 \mathrm{~h}$.

\begin{tabular}{ccccc}
\hline \multirow{2}{*}{ Comp. } & \multicolumn{4}{c}{ IC $_{\mathbf{5 0}}(\boldsymbol{\mu M})$} \\
\cline { 2 - 5 } & $\mathbf{A 5 4 9}$ & SW620 & SMMC-7721 & HaCaT \\
\hline $\mathbf{1}$ & $15.03 \pm 1.01$ & $26.48 \pm 0.59$ & $17.51 \pm 1.84$ & $27.26 \pm 1.49$ \\
$\mathbf{2}$ & $13.79 \pm 0.53$ & $27.23 \pm 0.53$ & $12.93 \pm 0.51$ & $17.48 \pm 0.58$ \\
$\mathbf{3}$ & $14.27 \pm 0.21$ & $16.02 \pm 0.29$ & $12.64 \pm 0.35$ & $13.37 \pm 0.56$ \\
$\mathbf{4}$ & $3.00 \pm 0.14$ & $16.52 \pm 0.28$ & $24.22 \pm 2.28$ & $13.94 \pm 0.64$ \\
cis-platin & $32.01 \pm 4.66$ & $6.29 \pm 0.17$ & $11.66 \pm 1.45$ & $18.48 \pm 1.64$ \\
\hline
\end{tabular}

\subsection{Apoptosis Induction}

According to the results of the MTT assay, flow cytometric analysis was carried out to further understand the underlying mechanisms of $\mathbf{1}$. In general, apoptosis and cell cycle arrest, or a combined action of both can result in growth inhibition or death of cells [16]. After A549 cells were exposed to different concentrations of $\mathbf{1}(0,5,10$, and $20 \mu \mathrm{M})$ for $24 \mathrm{~h}$, a significant increase in G1-phase was observed, and was dosage depend (Figure 1a). At concentration of $20 \mu \mathrm{M}$ for 1, the ratio of G1-phase reached about $67.37 \%$, which was about $12 \%$ higher than that of the control $(55.75 \%)[17,18]$. These data indicating that 1 may inhibit the growth of A549 cells through inducing apoptosis of tumor cells since G1 phase arrest was more related to cell apoptosis, and pro-apoptotic proteins like Bcl-2 usually plays key roles in accelerating the apoptosis of tumor cells [19-23]. 


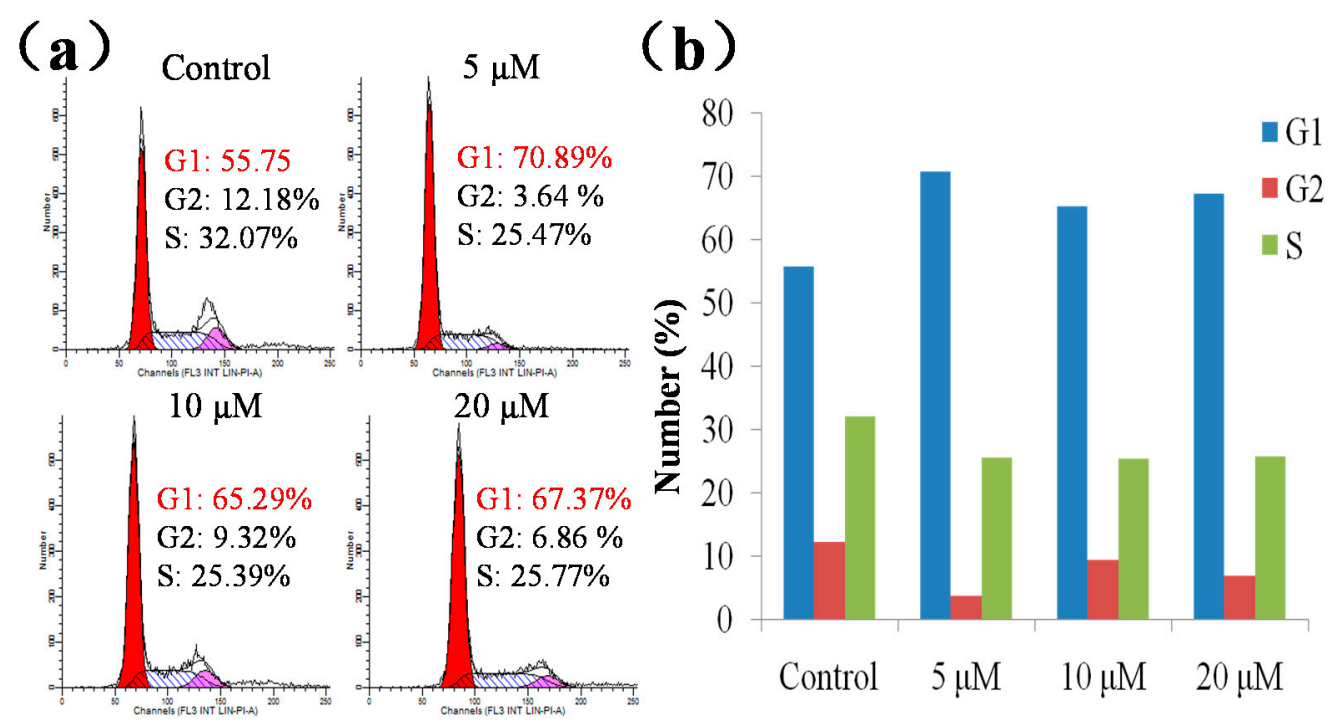

Figure 1. (a) G1-phase arrest of A549 cells induced by 1; (b) Change in cell cycle distribution of A549 cells induced by 1 . A549 cells were treated with $1(0,5,10$, and $20 \mu \mathrm{M})$ for $24 \mathrm{~h}$, almost $67.37 \%$ cycling cells were in the G1-phase and the sharp peak suggested that some cells were experiencing G1-phase delay or arrest.

\subsection{Drug Distribution and Location}

Cellular localization of $\mathbf{1}$ in A549 cells was further investigated, as shown in Figure 2. It was observed that 1 can be uptook by A549 cells and glow weak green fluorescence, a possible reason is mainly due to the absence of hypochrome nitro-group. Here, the mitochondria were marked in red by Mito-tracker, and the nuclei of A549 cells were stained blue by Hoechst 33,258. After incubated with 1 for $6 \mathrm{~h}$ at $37^{\circ} \mathrm{C}$, an green fluorescence was great merged with red fluorescence in the cell mitochondria, but little overlay in cell nucleus. These results indicated this compound entered into cells majorly accumulated in the mitochondria of A549 cells, which may induce the cell apoptosis through mitochondria-mediated pathway.

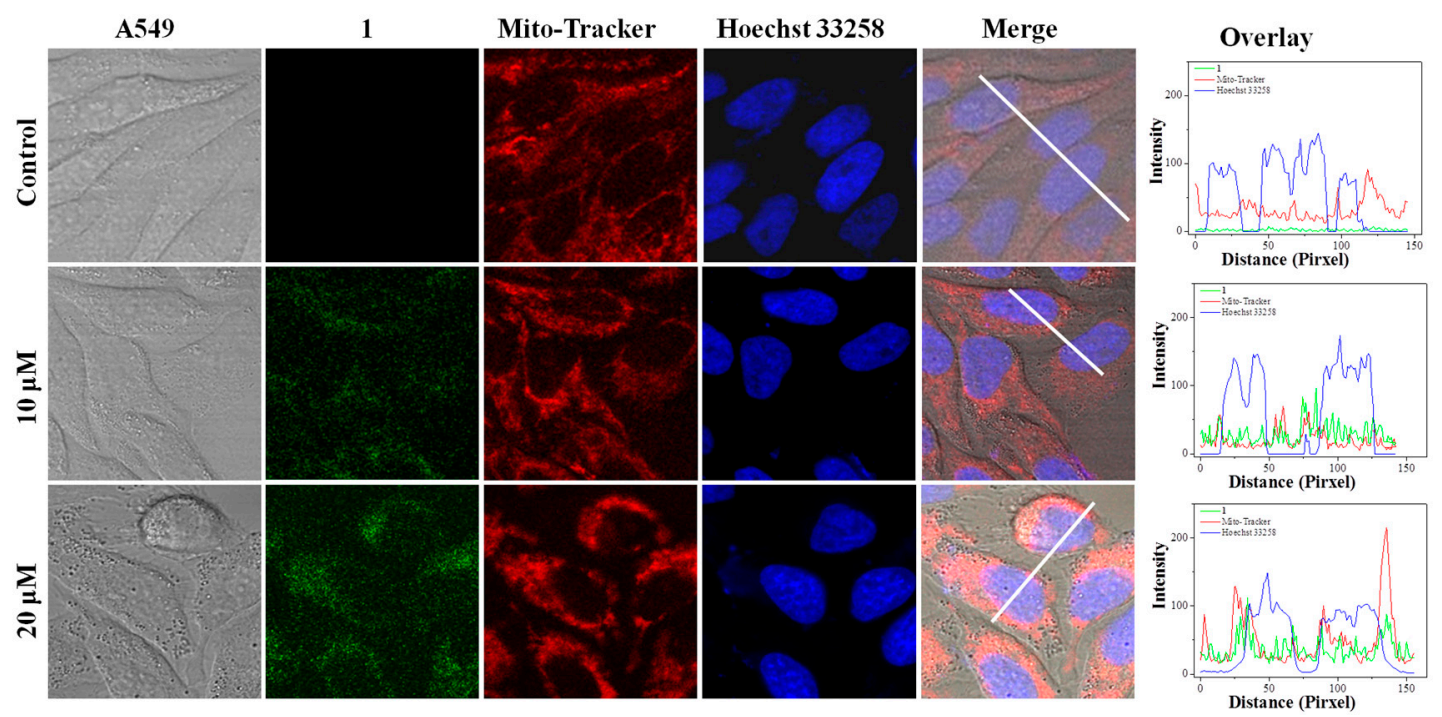

Figure 2. Cellular localization of $\mathbf{1}$ in A549 cells. Cells were treated with the $\mathbf{1}$ for $6 \mathrm{~h}$ at $37^{\circ} \mathrm{C}[\mathbf{1}]=0,10$ and $20 \mu \mathrm{M}$ : green, 1; blue, Hoechst 33258; red, Mito-Tracker. The overlay data were analyzed using Image Pro Plus. 


\subsection{The Interaction of Bcl-2 G-quadruplex DNA with Imidazo[4,5-f][1,10]phenanthroimidazole Derivatives}

\subsubsection{Electronic Titrations}

Electronic spectra titration experiment was carried out to monitor the interaction of 1 with $b c l-2$ G-quadruplex DNA. As shown in Figure 3a, the electronic spectra of 1 in Tris- $\mathrm{HCl}$ buffer $(\mathrm{pH}=7.2)$ solution exhibited the characteristic IL (intraligand charge transfer) absorption in the range of 250-300 $\mathrm{nm}$ with the maximum at about $273 \mathrm{~nm}$. When the DNA was gradually added to the solution of the complex, a hyperchromic effect and a bathochromic effect were observed. The hyperchromism value of 1 at the IL absorption band was about $14.1 \%(\Delta \lambda=2.1 \mathrm{~nm})$, which may be attributed to bases of the DNA exposed, when the ligand binding to DNA, induced external contact or to partial uncoiling of the DNA structure $[24,25]$. Furthermore, the value of the intrinsic binding constant $\left(K_{b}\right)$ for $\mathbf{1}$ was about $8.7 \times 10^{7} \mathrm{M}^{-1}$, calculated according to the decay of IL absorption. These data implied that 1 bound to $b c l-2$ G-quadruplex DNA with high affinity in intercalating mode [26]. The interaction was further confirmed by the following fluorescence quenching experiment.

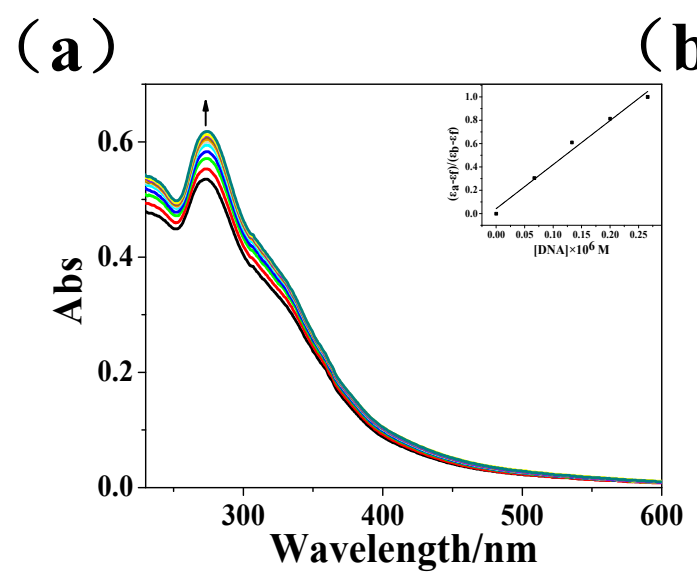

(b)

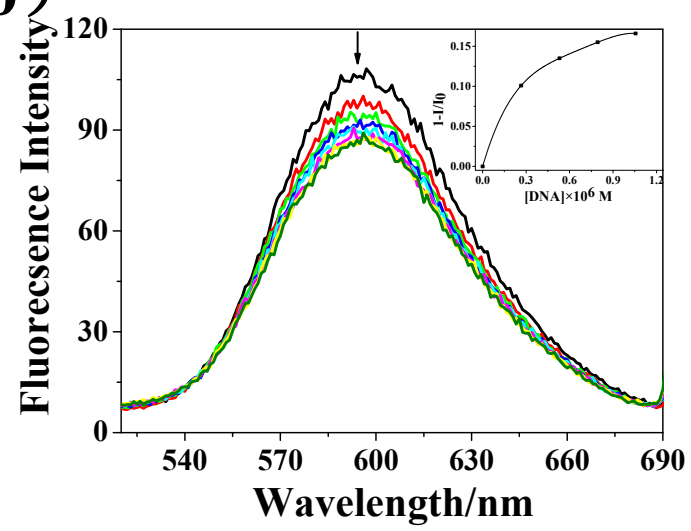

Figure 3. The study of the interaction between $\mathbf{1}$ with $b c l-2$ G-quadruplex DNA by spectroscopic methods. (a) The electronic spectra of $\mathbf{1}$ in absence and in presence of $b c l-2$ G-quadruplex DNA. [1] $=60 \mu \mathrm{M}$, [DNA] $=100 \mu \mathrm{M}$; (b) Emission spectra of EB and bcl-2 G-quadruplex DNA in the incubation buffer in the absence and presence of $\mathbf{1},[\mathrm{EB}]=16 \mu \mathrm{M},[\mathrm{DNA}]=2 \mu \mathrm{M}$.

\subsubsection{Fluorescence Quenching}

Owing to the low fluorescence of 1 in the Tris- $\mathrm{HCl} \mathrm{KCl}$ buffer $(\mathrm{pH}=7.2)$, fluorescence quenching of ethidium bromide (EB) and DNA was carried out. As shown in Figure 3b, when excited at $350 \mathrm{~nm}$, the EB-DNA ( $b c l-2$ G4 DNA) emitted a strong fluorescence in the range of $500 \mathrm{~nm}$ to $700 \mathrm{~nm}$ with the maximum at about $597 \mathrm{~nm}$ [27]. Upon the addition of 1, it was observed the fluorescence intensity of the solution decreased gradually. At $[1]=20.89 \mu \mathrm{M}$, the relative intensity $\left(I / I_{0}\right)$ for solution was about 0.83 . The results implied that 1 exhibited a certain interaction with $b c l-2$ G-quadruplex DNA.

\subsubsection{FRET Melting Point Curves}

To confirm the stability of the $b c l-2$ G4 DNA in presence of $\mathbf{1}$, FRET melting assay was carried out, the results were shown in Figure $4 \mathrm{a}$, and the melting point of the concentration-dependent melting curves of 1 were showed in Figure $4 \mathrm{~b}$. Treated with $3.0 \mu \mathrm{M}$ of $\mathbf{1}$, the $\Delta T_{\mathrm{m}}$ of $b c l-2 \mathrm{G} 4$ DNA was about $2.4{ }^{\circ} \mathrm{C}$, while the $\Delta T_{\mathrm{m}}$ of $b c l-2 \mathrm{G} 4$ DNA increased about $11^{\circ} \mathrm{C}$ after incubated with increasing the concentration $6.0 \mu \mathrm{M}$ of $\mathbf{1}$. These results indicated that 1 behaved to stabilize $b c l-2 \mathrm{G}$-quadruplex DNA [28]. 


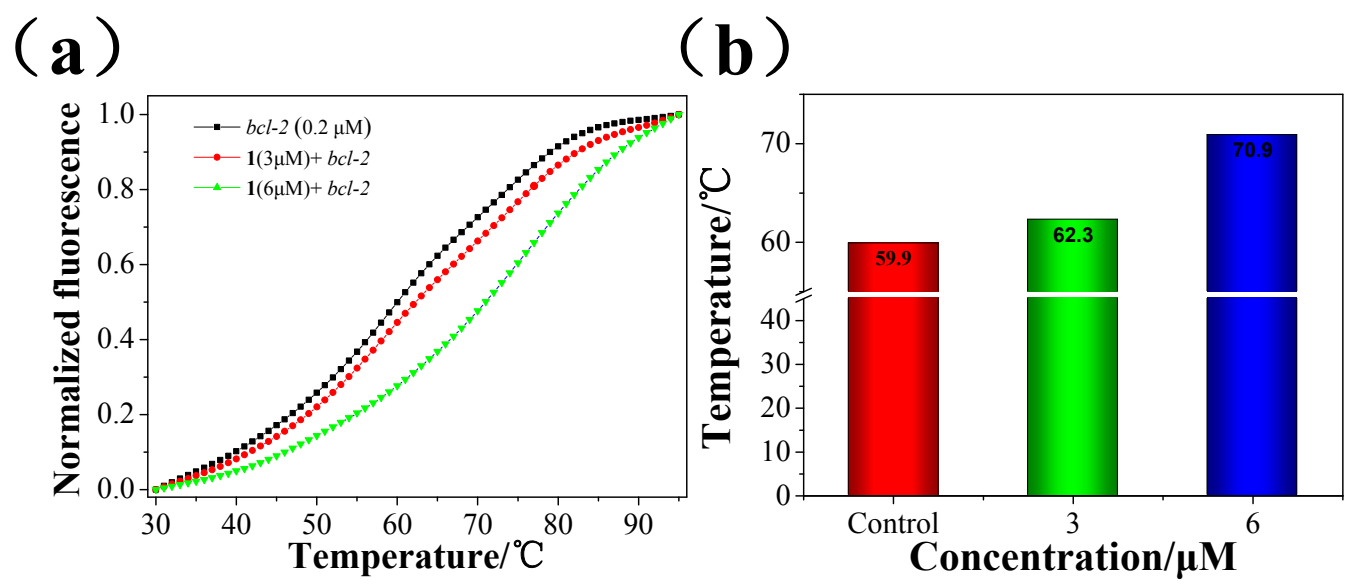

Figure 4. FRET melting profiles of $b c l-2$ G4 DNA in the absence and in presence of $\mathbf{1}$ (a) ([bcl-2 G4 $\mathrm{DNA}]=0.2 \mu \mathrm{M})$ and the melting rising trend with the increasing of $\mathbf{1}(\mathbf{b})$.

\section{Experimental Section}

\subsection{Materials}

All reagents were purchased from commercial suppliers and used without further purification. Solvents were dried and purified by conventional methods prior to use. Distilled water was used in all experiments. Bcl-2 G-quadruplex DNA (5'-CGGGCGCGGGAGGAAGGGGGCGGGAGC-3') and 5'-FAM-bcl-2-TAMRA-3' were purchased from Sangon Biotech Co., Ltd. (Shanghai, China) Bcl-2 G-quadruplex DNA formed a G-quadruplex conformation as literature by renaturation for $24 \mathrm{~h}$ at $4{ }^{\circ} \mathrm{C}$, after denaturation for $5 \mathrm{~min}$ at $90{ }^{\circ} \mathrm{C}$ [29]. All aqueous solutions were prepared with doubly distilled water. The Tris- $\mathrm{HCl}$ buffer consisting of Tris and $\mathrm{KCl}$, and the $\mathrm{pH}$ value was adjusted to $7.2 \mathrm{by} \mathrm{HCl}$ solution, which was applied to UV titration, Fluorescence emission titrations.

\subsection{Instruments}

The imidazo[4,5- $f][1,10]$ phenanthroline derivatives were synthesized by using Anton Paar Monowave 300 microwave reactor (Anton Paar, Graz, Austria). ESI-MS spectra were obtained in methanol on Agilent 1100 ESI-MS system (Agilent, Palo Alto, CA, USA) operating at room temperature. The ${ }^{1} \mathrm{H}-\mathrm{NMR}$ and ${ }^{13} \mathrm{C}-\mathrm{NMR}$ spectra were recorded on a dimethyl- $d_{6}$ sulfoxide (DMSO- $d_{6}$ ) solution on a Bruker Avance III 500 spectrometer (Bruker, Bremen, Germany) operating at room temperature. The HPLC spectra were recorded on a Agilent 1200 high pressure liquid chromatograph (Agilent, Palo Alto, CA, USA). UV-vis absorption spectra were recorded on a Shimadzu UV-2550 spectrophotometer (Shimadzu, Tokyo, Japan). The steady-state emission spectra were recorded on a RF-5301 fluorescence spectrophotometer (Shimadzu, Tokyo, Japan). Cellular localization experiment was performed with an LSCM510 Meta Duo Scan (Carl Zeiss, Oberkochen, Germany).

\subsection{Synthesis of Imidazole[4,5-f][1,10] phenantholine Derivatives}

Imidazole[4,5- $f][1,10]$ phenanthroimidazole derivatives were synthesized according to the literature procedure with some modification [30]. All of the compounds were appropriately characterized and the HPLC analysis showed the average purity of target compounds was about $97 \%$ (see Supplementary Materials).

\subsubsection{Synthesis of $\mathbf{1}$}

A mixture of 1,10-phenanthroline-5,6-dione $(315.06 \mathrm{mg}, 1.50 \mathrm{mmol})$, 3-nitrobenzaldehyde (339.81 mg, $2.25 \mathrm{mmol})$, ammonium acetate $(4 \mathrm{~g}, 51.9 \mathrm{mmol})$ and glacial acetic acid $(20 \mathrm{~mL})$ was heated at $100{ }^{\circ} \mathrm{C}$ for $20 \mathrm{~min}$ under microwave irradiation. Then, $20 \mathrm{~mL}$ of water was added and the 
$\mathrm{pH}$ value was adjusted to 7.0 at room temperature. The solution was filtered and dried in vacuum to obtain a yellow precipitate, which was collected and washed with water and small amounts of ethanol. The crude product dissolved in ethanol was purified by filtration on silicagel column (60-100 mesh). ESI-MS (in $\mathrm{MeOH}, m / z$ ): $342.1[\mathrm{M}+\mathrm{H}]^{+}$. Anal. Calcd. for $\mathrm{C}_{19} \mathrm{H}_{11} \mathrm{~N}_{5} \mathrm{O}_{2} \cdot \mathrm{CH}_{3} \mathrm{COOH}$ : C, 62.84; $\mathrm{H}$, 3.77; $\mathrm{N}, 17.45$. Found: C, 61.66; H, 3.69; N, 18.72. ${ }^{1} \mathrm{H}-\mathrm{NMR}(500 \mathrm{MHz}, \mathrm{DMSO}) \delta 9.03-9.02(\mathrm{~m}, 1 \mathrm{H}), 9.00(\mathrm{dd}$, $J=4.3,1.7 \mathrm{~Hz}, 2 \mathrm{H}), 8.84(\mathrm{dd}, J=8.1,1.7 \mathrm{~Hz}, 2 \mathrm{H}), 8.64(\mathrm{~d}, J=8.0 \mathrm{~Hz}, 1 \mathrm{H}), 8.27(\mathrm{dd}, J=8.1,1.5 \mathrm{~Hz}, 1 \mathrm{H})$, $7.83(\mathrm{t}, J=8.0 \mathrm{~Hz}, 1 \mathrm{H}), 7.78(\mathrm{dd}, J=8.1,4.3 \mathrm{~Hz}, 2 \mathrm{H}) .{ }^{13} \mathrm{C}-\mathrm{NMR}(126 \mathrm{MHz}, \mathrm{DMSO}) \delta 150.38(\mathrm{~s}), 145.70(\mathrm{~s})$, $134.14(\mathrm{~s}), 132.63$ (s), 131.70 (s), 125.58 (s), 125.29 (s), 122.30 (s), HPLC purity, 98.2\% at $273 \mathrm{~nm}$ (method $\left.\mathrm{A}, t_{\mathrm{R}}=4.72 \mathrm{~min}\right)$.

\subsubsection{Synthesis of 2}

2 was prepared using the method described above, but with 3-trifluoromethylbenzaldehyde (391.5 mg, $2.25 \mathrm{mmol}$ ). ESI-MS (in $\mathrm{MeOH}, m / z)$ : $365.5[\mathrm{M}+\mathrm{H}]^{+}$. Anal. Calcd. for $\mathrm{C}_{20} \mathrm{H}_{11} \mathrm{~F}_{3} \mathrm{~N}_{4}$. $\mathrm{H}_{2} \mathrm{O} \cdot \mathrm{CH}_{3} \mathrm{CH}_{2} \mathrm{OH}$ : C, 61.68; H, 4.47; N, 13.08. Found: C, 62.23; H, 4.26; N, 13.70. ${ }^{1} \mathrm{H}-\mathrm{NMR}(500 \mathrm{MHz}$, DMSO) $\delta 9.00(\mathrm{dd}, J=4.3,1.7 \mathrm{~Hz}, 2 \mathrm{H}), 8.84(\mathrm{dd}, J=8.1,1.6 \mathrm{~Hz}, 2 \mathrm{H}), 8.55(\mathrm{~s}, 1 \mathrm{H}), 8.53(\mathrm{~d}, J=7.3 \mathrm{~Hz}, 1 \mathrm{H})$, $7.84(\mathrm{t}, J=3.6 \mathrm{~Hz}, 2 \mathrm{H}), 7.78(\mathrm{dd}, J=8.1,4.3 \mathrm{~Hz}, 2 \mathrm{H}) .{ }^{13} \mathrm{C}-\mathrm{NMR}(126 \mathrm{MHz}, \mathrm{DMSO}) \delta 150.88(\mathrm{~s}), 149.99(\mathrm{~s})$, $145.75(\mathrm{~s}), 133.03(\mathrm{~s}), 132.29(\mathrm{~s}), 131.98(\mathrm{~s}), 131.64(\mathrm{~s}), 125.30(\mathrm{~s})$, HPLC purity, $99.3 \%$ at $273 \mathrm{~nm}$ (method $\left.\mathrm{A}, t_{\mathrm{R}}=7.84 \mathrm{~min}\right)$.

\subsubsection{Synthesis of 3}

3 was prepared using the method described above, but with 3-chlorobenzaldehyde (315 $\mathrm{mg}$, $2.25 \mathrm{mmol}$ ). ESI-MS (in $\mathrm{MeOH}, \mathrm{m} / z$ ): $331.3[\mathrm{M}+\mathrm{H}]^{+}$. Anal. Calcd. for $\mathrm{C}_{19} \mathrm{H}_{11} \mathrm{ClN}_{4} \cdot \mathrm{H}_{2} \mathrm{O} \cdot \mathrm{CH}_{3} \mathrm{COOH}$ : C, 61.69; H, 4.19; N, 13.70. Found: C, 61.62; H, 3.95; N, 14.13. ${ }^{1} \mathrm{H}-\mathrm{NMR}\left(500 \mathrm{MHz}, \mathrm{MeOD}: \mathrm{CDCl}_{3}=1: 1\right)$ $\delta 8.95-8.89(\mathrm{~m}, 2 \mathrm{H}), 8.79(\mathrm{~s}, 1 \mathrm{H}), 7.99(\mathrm{t}, J=9.4 \mathrm{~Hz}, 2 \mathrm{H}), 7.62(\mathrm{~s}, 2 \mathrm{H}), 7.57(\mathrm{~s}, 1 \mathrm{H}), 7.29(\mathrm{t}, J=8.7 \mathrm{~Hz}$, 2H). ${ }^{13} \mathrm{C}-\mathrm{NMR}\left(126 \mathrm{MHz}, \mathrm{MeOD}: \mathrm{CDCl}_{3}=1: 1\right) \delta 149.06$ (s), 144.91 (s), 141.69 (s), 131.63-131.46 (m), $131.08(\mathrm{~s}), 127.96(\mathrm{~s}), 124.76(\mathrm{~s}), \mathrm{HPLC}$ purity, $98.8 \%$ at $273 \mathrm{~nm}\left(\right.$ method $\left.\mathrm{A}, t_{\mathrm{R}}=6.30 \mathrm{~min}\right)$.

\subsubsection{Synthesis of 4}

4 was prepared using the method described above, but with 3-Hydroxybenzaldehyde ( $274.59 \mathrm{mg}$, $2.25 \mathrm{mmol}$ ). ESI-MS (in $\mathrm{MeOH}, \mathrm{m} / z$ ): $313.1[\mathrm{M}+\mathrm{H}]^{+}$. Anal. Calcd for $\mathrm{C}_{19} \mathrm{H}_{12} \mathrm{~N}_{4} \mathrm{O} \cdot \mathrm{H}_{2} \mathrm{O} \cdot \mathrm{CH}_{3} \mathrm{CH}_{2} \mathrm{OH}$ : C, 67.01; H, 5.36; N, 14.88. Found: C, 67.06; H, 5.20; N, 15.25. ${ }^{1} \mathrm{H}-\mathrm{NMR}$ (500 MHz, DMSO) $\delta 9.02$ (dd, $J=4.3,1.7 \mathrm{~Hz}, 2 \mathrm{H}), 8.91(\mathrm{dd}, J=8.1,1.7 \mathrm{~Hz}, 2 \mathrm{H}), 7.81(\mathrm{dd}, J=8.1,4.3 \mathrm{~Hz}, 2 \mathrm{H}), 7.73(\mathrm{dd}, J=6.0,3.8 \mathrm{~Hz}$, $1 \mathrm{H}), 7.72-7.69(\mathrm{~m}, 1 \mathrm{H}), 7.39(\mathrm{t}, J=7.9 \mathrm{~Hz}, 1 \mathrm{H}), 6.91(\mathrm{ddd}, J=8.1,2.4,0.8 \mathrm{~Hz}, 1 \mathrm{H}) .{ }^{13} \mathrm{C}-\mathrm{NMR}(126 \mathrm{MHz}$, DMSO) $\delta 152.95$ (s), 149.75 (s), 145.55 (s), 133.43 (s), 132.07 (s), 131.68 (s), 125.30 (s), 119.07 (s), 118.72 (s), $115.16(\mathrm{~s})$, HPLC purity, $93.2 \%$ at $273 \mathrm{~nm}\left(\operatorname{method} \mathrm{A}, t_{\mathrm{R}}=4.17 \mathrm{~min}\right)$.

\subsection{Cell Lines, Cell Culture and MTT Assay}

Human cancer cell lines, human lung adenocarcinoma A549 cells, human hepatocarcinoma SMMC7721 cells, human colorectal carcinoma SW620 cells and HaCaT cells were purchased from American Type Culture Collection (ATCC, Manassas, VA, USA). All cell lines were maintained in Dulbecco's Modified Eagle Medium (DMEM) media supplemented with fetal bovine serum $(10 \%)$, penicillin (100 units $/ \mathrm{mL}$ ), and streptomycin $(50$ units $/ \mathrm{mL})$ at $37^{\circ} \mathrm{C}$ in a $\mathrm{CO}_{2}$ incubator $(95 \%$ relative humidity, $5 \% \mathrm{CO}_{2}$ ).

Cell viability was confirmed by measuring the ability of cells to transform 3-(4, 5-dimethylthia-zol-2-yl)-2,5-diphenyltetrazolium bromide (MTT) to a purple formazan dye [31]. Cells were seeded in 96-well tissue culture plates $\left(3 \times 10^{3}\right.$ cells per well) for $24 \mathrm{~h}$. The cells were then incubated with the tested compounds at different concentrations for $72 \mathrm{~h}$. After incubation, $20 \mu \mathrm{L}$ per well of MTT solution ( $5 \mathrm{mg} / \mathrm{mL}$ in phosphate buffered saline, PBS) was added, followed by incubation for a further $5 \mathrm{~h}$. The medium was aspirated and replaced with $150 \mu \mathrm{L} /$ well of DMSO to dissolve the formazan salt formed. The colour intensity, which reflects the cell growth condition, was measured 
at $570 \mathrm{~nm}$ using a microplate spectrophotometer (SpectroAmaxTM250, BioTek Instruments, Inc., Winooski, VT, USA).

\subsection{Flow Cytometric Analysis}

Cells were seeded in six-well tissue culture plates $\left(1 \times 10^{5}\right.$ cells per well), and the cell cycle arrest was analyzed by flow cytometry as previously described [32]. After incubating with different concentrations of $\mathbf{1}(0,5,10$, and $20 \mu \mathrm{M})$ for $72 \mathrm{~h}$, cells were trypsinized, washed with PBS, and fixed with $70 \%$ ethanol overnight at $4{ }^{\circ} \mathrm{C}$. The fixed cells were washed with PBS and stained with propidium iodide (PI) for $15 \mathrm{~min}$ in the dark, then the cell cycle arrest was analyzed with an Epics XL-MCL flow cytometer (Beckman Coulter, Miami, FL, USA).

\subsection{Cellular Localization}

Cells were cultured in DMEM medium supplemented with $10 \%$ fetal bovine serum (FBS) at $37^{\circ} \mathrm{C}$ under $5 \% \mathrm{CO}_{2}$. Cells in complete growth medium at $5 \times 10^{4}$ cells per $\mathrm{mL}$ were incubated for $6 \mathrm{~h}$ at $37^{\circ} \mathrm{C}$. Cells were treated with 1 in DMEM for $6 \mathrm{~h}$ at $37^{\circ} \mathrm{C}$ under $5 \% \mathrm{CO}_{2}$. Then, cells were stained with Mito-tracker and Hoechst 33,258 for another $20 \mathrm{~min}$, and finally, luminescence imaging was carried out by confocal laser scanning microscope.

\subsection{Electronic Absorption Measurements}

Electronic absorption spectra were recorded on a Shimadzu UV-2550 spectrophotometer using $1 \mathrm{~cm}$ path length quartz cuvettes $(3 \mathrm{~mL})$. The absorption titration of the target complex in Tris-HCl buffer was performed by using a fixed complex concentration to which increments of the DNA stock solution were added. The concentration of the complex solution was $20 \mu \mathrm{M}$ and $b c l-2 \mathrm{G} 4$ DNA was added by degrees. Complex-DNA solutions were allowed to incubate for $3 \mathrm{~min}$ before the absorption spectra were recorded.

\subsection{Fluorescence Quenching Measurements}

Fluorescence spectroscopy measurements were performed on a RF-5301 fluorescence spectrophotometer using a $1 \mathrm{~cm}$ path length quartz cell. Fluorescence quenching of the EB $+b c \mathrm{l}-2 \mathrm{G} 4$ DNA system can be used for a compound having an affinity to DNA in spite of its binding mode, and only measures the ability of the compound to affect the EB fluorescence intensities in the EB + bcl-2 G4 DNA system. The titration processes were repeated until there was no apparent change in the spectra for at least three titrations, indicating the achievement of the binding saturation [33].

\subsection{FRET Melting Assays}

The fluorescent labeled oligonucleotide, $b c l-2$ G-quadruplex DNA (5'-FAM-CGGGCGC GGGAGGAAGGGGGCGGGAGC-TAMRA-3', FAM: carboxyfluorescein, TAMRA: 6-carboxy tetramethylrhodamine) used as the FRET probe was diluted in Tris $\mathrm{HCl}$ buffer and then annealed by being heated to $90^{\circ} \mathrm{C}$ for $5 \mathrm{~min}$, followed by slowly cooling to room temperature [29]. Ds26 duplex DNA (CAATCGGATCGAATTCGATCCGATTG) was competitive binders to evaluate the selective binding ability of 1 with $b c l-2$ G4 DNA. Fluorescence melting curves were determined with a Bio-RadiQ5 realtime PCR detection system (Bio-Rad, Berkeley, CA, USA), by using a total reaction volume of $25 \mathrm{~mL}$, with labeled oligonucleotide $(1 \mu \mathrm{M})$ and different concentrations of complex in Tris- $\mathrm{HCl}$ buffer [34]. A constant temperature was maintained for $30 \mathrm{~s}$ prior to each reading to ensure a stable value. Final analysis of the data was carried out by using Origin7.5 (Origin Lab, Northampton, MA, USA). 


\section{Conclusions}

In summary, a series of imidazole[4,5- $f][1,10]$ phenanthroimidazole derivatives have been synthesized by using microwave-assisted synthesis technology, with high yields of approximately $90 \%$, which can rapid rising to the required temperature, and kept almost no change during the whole process. The results of MTT assay showed these complexes can block the growth of tumor cells, especially 1, exhibited excellent antitumor activity against A549 cells through inducing apoptosis of the cells. The further study displayed $\mathbf{1}$ can distribute at mitochondria, and inhibit tumor cells at G1 phase then induce apoptosis. Furthermore, this compound can bind to the $b c l-2$ G-quadruplex DNA. Take together, the results suggested that the target compound could act as a potential apoptosis inducer mediated-mitochondria through binding to the $b c l-2$ G-quadruplex DNA in cancer chemotherapy (Figure 5).

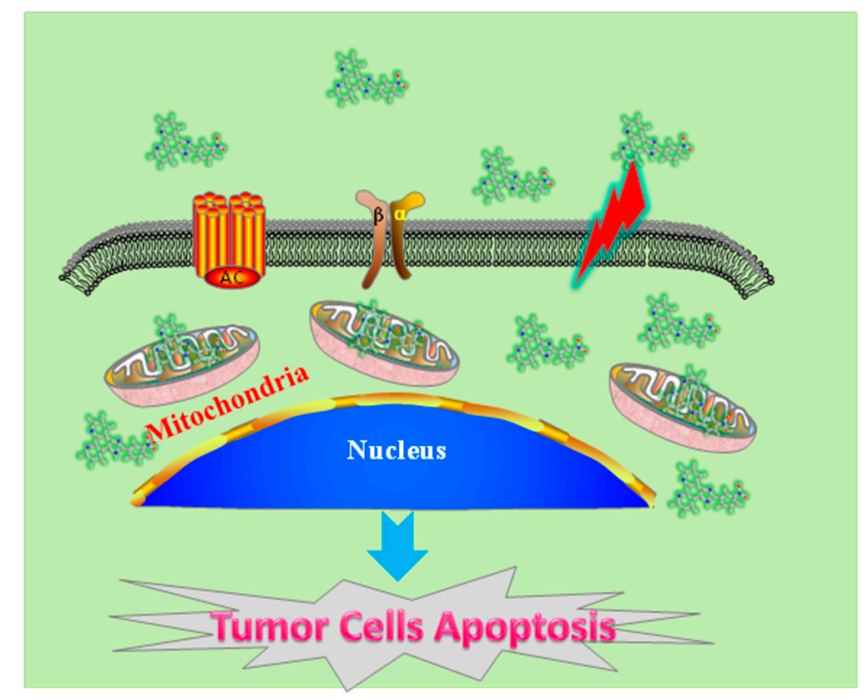

Figure 5. Tumor cells apoptosis induced by imidazole[4,5- $f][1,10]$ phenanthroimidazole derivatives related to mitochondria-mediated pathway.

Supplementary Materials: Supplementary materials are available online.

Acknowledgments: This work was supported by National Nature Science Foundation of China (81572926); the Provincial Major Scientific Research Projects in Universities of Guangdong Province (2014KZDXM053); the Science and Technology Project of Guangdong Province (2014A020212312); the Innovation Projects in Universities of Guangdong Province (2015cxqx151); Tradition Chinese Medicine Bureau of Guangdong Province (number 20151265), the Innovation Team Projects in Universities of Guangdong Province (2016KCXTD018).

Author Contributions: Li Li and Jie-Qing Cao contribute to electronic spectra titration, emission spectra, and Li Li writes the paper. Hui-Min Liu contributes to the FRET melting assay. Yu-Mei Li contributes to the synthesis of the target complexes; Qiu-Hui Pan, Qiong-Wu, Zhi-Ping Zeng and Yu-Tao Lan contribute to the cells experiments. Xi-Cheng Wan, Wen-Jie Mei and Wen-Jie Zheng contributed to designed the experiments and read the manuscript.

Conflicts of Interest: The authors declare no conflict of interest.

\section{References}

1. De Cian, A.; Delemos, E.; Mergny, J.L.; Teulade-Fichou, M.P.; Monchaud, D. Highly efficient G-quadruplex recognition by bisquinolinium compounds. J. Am. Chem. Soc. 2007, 129, 1856-1857. [CrossRef] [PubMed]

2. Zhen, N.; Yang, Q.; Zheng, K.; Han, Z.; Sun, F.; Mei, W.; Yu, Y. MiroRNA-127-3p targets XRCC3 to enhance the chemosensitivity of esophageal cancer cells to a novel phenanthroline-dione derivative. Int. J. Biochem. Cell. B 2016, 79, 158-167. [CrossRef] [PubMed] 
3. Peng, J.; Sun, J.; Gong, P.; Xue, P.; Zhang, Z.; Zhang, G.; Lu, R. Luminescent Nanofibers Fabricated from Phenanthroimidazole Derivatives by Organogelation: Fluorescence Response towards Acid with High Performance. Chem. Asian J. 2015, 10, 1717-1724. [CrossRef] [PubMed]

4. Wang, L.; Wen, Y.; Liu, J.; Zhou, J.; Li, C.; Wei, C. Promoting the formation and stabilization of human telomeric G-quadruplex DNA, inhibition of telomerase and cytotoxicity by phenanthroline derivatives. Org. Biomol. Chem. 2011, 9, 2648-2653. [CrossRef] [PubMed]

5. Wei, C.Y.; Wang, J.H.; Wen, Y.; Liu, J.; Wang, L.H. 4-(1H-imidazo[4,5-f]-1,10-phenanthrolin-2-yl)phenol-based G-quadruplex DNA binding agents: Telomerase inhibition, cytotoxicity and DNA-binding studies. Bioorg. Med. Chem. 2013, 21, 3379-3387. [CrossRef] [PubMed]

6. Liao, S.; Zhang, Z.; Wu, Q.; Wang, X.; Mei, W. Microwave-assisted synthesis of phenanthroimidazole derivatives as stabilizer of $c-m y c$ G-quadruplex DNA. Bioorg. Med. Chem. 2014, 22, 6503-6508. [CrossRef] [PubMed]

7. Zhen, N.; Yang, Q.; Wu, Q.; Zhu, X.; Wang, Y.; Sun, F.; Mei, W.; Yu, Y. A novelly synthesized phenanthroline derivative is a promising DNA-damaging anticancer agent inhibiting G1/S checkpoint transition and inducing cell apoptosis in cancer cells. Cancer Chemother. Pharmacol. 2016, 77, 169-180. [CrossRef] [PubMed]

8. Wang, C.; Yu, Q.; Yang, L.; Liu, Y.; Sun, D.; Huang, Y.; Zhou, Y.; Zhang, Q.; Liu, J. Ruthenium (II) polypyridyl complexes stabilize the bcl-2 promoter quadruplex and induce apoptosis of Hela tumor cells. Biometals 2013, 26, 387-402. [CrossRef] [PubMed]

9. Feng, Y.; Yang, D.; Chen, H.; Cheng, W.; Wang, L.; Sun, H.; Tang, Y. Stabilization of G-quadruplex DNA and inhibition of Bcl-2 expression by a pyridostatin analog. Bioorg. Med. Chem. Lett. 2016, 26, 1660-1663. [CrossRef] [PubMed]

10. Chen, Z.F.; Qin, Q.P.; Qin, J.L.; Liu, Y.C.; Huang, K.B.; Li, Y.L.; Meng, T.; Zhang, G.H.; Peng, Y.; Luo, X.J.; et al. Stabilization of G-quadruplex DNA, inhibition of telomerase activity, and tumor cell apoptosis by organoplatinum(II) complexes with oxoisoaporphine. J. Med. Chem. 2015, 58, 2159-2179. [CrossRef] [PubMed]

11. Wang, X.D.; Ou, T.M.; Lu, Y.J.; Li, Z.; Xu, Z.; Xi, C.; Tan, J.H.; Huang, S.L.; An, L.K.; Li, D.; et al. Turning off transcription of the bcl-2 gene by stabilizing the bcl-2 promoter quadruplex with quindoline derivatives. J. Med. Chem. 2010, 53, 4390-4398. [CrossRef] [PubMed]

12. Kitchen, H.J.; Vallance, S.R.; Kennedy, J.L.; Tapia-Ruiz, N.; Carassiti, L.; Harrison, A.; Whittaker, A.G.; Drysdale, T.D.; Kingman, S.W.; Gregory, D.H. Modern microwave methods in solid-state inorganic materials chemistry: From fundamentals to manufacturing. Chem. Rev. 2014, 114, 1170-1206. [CrossRef] [PubMed]

13. De la Hoz, A.; Diaz-Ortiz, A.; Moreno, A. Microwaves in organic synthesis. Thermal and non-thermal microwave effects. Chem. Soc. Rev. 2005, 34, 164-178. [CrossRef] [PubMed]

14. Beckford, F.A.; Shaloski, M.; Leblanc, G.; Thessing, J.; Lewis-Alleyne, L.C.; Holder, A.A.; Li, L.; Seeram, N.P. Microwave synthesis of mixed ligand diimine-thiosemicarbazone complexes of ruthenium(II): Biophysical reactivity and cytotoxicity. Dalton Trans. 2009, 48, 10757-10764. [CrossRef] [PubMed]

15. Sun, D.-D.; Wang, W.Z.; Mao, J.W.; Mei, W.J.; Liu, J. Imidazo[4,5-f][1,10]phenanthroline derivatives as inhibitor of $c-m y c$ gene expression in A549 cells via NF-kB pathway. Bioorg. Med. Chem. Lett. 2012, 22, 102-105. [CrossRef] [PubMed]

16. Xiao, H.; Zhang, Q.; Lin, Y.; Reddy, B.S.; Yang, C.S. Combination of atorvastatin and celecoxib synergistically induces cell cycle arrest and apoptosis in colon cancer cells. Int. J. Cancer 2008, 122, 2115-2124. [CrossRef] [PubMed]

17. Wang, T.; Gong, X.; Jiang, R.; Li, H.; Du, W.; Kuang, G. Ferulic acid inhibits proliferation and promotes apoptosis via blockage of PI3K/Akt pathway in osteosarcoma cell. Am. J. Transl. Res. 2016, 8, 968-980. [PubMed]

18. Guo, Y.X.; Lin, Z.M.; Wang, M.J.; Dong, Y.W.; Niu, H.M.; Young, C.Y.; Lou, H.X.; Yuan, H.Q. Jungermannenone A and B induce ROS- and cell cycle-dependent apoptosis in prostate cancer cells in vitro. Acta Pharmacol. Sin. 2016, 37, 814-824. [CrossRef] [PubMed]

19. Varshavsky, A. The N-end rule pathway and regulation by proteolysis. Protein Sci. 2011, 20, 1298-1345. [CrossRef] [PubMed]

20. Eldeeb, M.-A.; Fahlman, R.P. Phosphorylation Impacts N-end Rule Degradation of the Proteolytically Activated Form of BMX Kinase. J. Biol. Chem. 2016, 291, 22757-22768. [CrossRef] [PubMed] 
21. Eldeeb, M.A.; Fahlman, R.P. The anti-apoptotic form of tyrosine kinase Lyn that is generated by proteolysis is degraded by the $\mathrm{N}$-end rule pathway. Oncotarget 2014, 5, 2714-2722. [CrossRef] [PubMed]

22. Song, Y.; Cao, W.; Zhu, X.; Qiu, Z.; Yang, X.; Liu, J.; Xu, R.; Yuan, W.; Quan, S. F10, a novel hydatidiform mole-associated gene, inhibits the paclitaxel sensitivity of A549 lung cancer cells by downregulating BAX and caspase-3. Oncol. Lett. 2017, 13, 2563-2568. [CrossRef] [PubMed]

23. Rauzan, M.; Chuah, C.T.; Ko, T.K.; Ong, S.T. The HDAC inhibitor SB939 overcomes resistance to BCR-ABL kinase Inhibitors conferred by the BIM deletion polymorphism in chronic myeloid leukemia. PLoS ONE 2017, 12, e0174107. [CrossRef] [PubMed]

24. Bhattacharjee, S.; Chakraborty, S.; Sengupta, P.K.; Bhowmik, S. Exploring the Interactions of the Dietary Plant Flavonoids Fisetin and Naringenin with G-Quadruplex and Duplex DNA, Showing Contrasting Binding Behavior: Spectroscopic and Molecular Modeling Approaches. J. Phys. Chem. B 2016, 120, 8942-8952. [CrossRef] [PubMed]

25. Buraka, E.; Chen, C.Y.; Gavare, M.; Grube, M.; Makarenkova, G.; Nikolajeva, V.; Bisenieks, I.; Bruvere, I.; Bisenieks, E.; Duburs, G.; et al. DNA-binding studies of AV-153, an antimutagenic and DNA repair-stimulating derivative of 1,4-dihydropiridine. Chem. Biol. Interact. 2014, 220, 200-207. [CrossRef] [PubMed]

26. Jager, K.; Bats, J.W.; Ihmels, H.; Granzhan, A.; Uebach, S.; Patrick, B.O. Polycyclic azoniahetarenes: Assessing the binding parameters of complexes between unsubstituted ligands and G-quadruplex DNA. Chemistry 2012, 18, 10903-10915. [CrossRef] [PubMed]

27. Wu, Q.; Chen, T.; Zhang, Z.; Liao, S.; Wu, X.; Wu, J.; Mei, W.; Chen, Y.; Wu, W.; Zeng, L.; et al. Microwave-assisted synthesis of arene ruthenium(II) complexes $\left[\left(\eta^{6}-{ }_{\mathrm{R}} \mathrm{C}_{6} \mathrm{H}_{5}\right) \mathrm{Ru}(\mathrm{m}-\mathrm{MOPIP}) \mathrm{Cl}\right] \mathrm{Cl}(\mathrm{R}=-\mathrm{H}$ and $-_{\mathrm{C}} \mathrm{H}_{3}$ ) as groove binder to $c$-myc G4 DNA. Dalton Trans. 2014, 43, 9216-9225. [CrossRef] [PubMed]

28. Peng, D.; Tan, J.H.; Chen, S.B.; Ou, T.M.; Gu, L.Q.; Huang, Z.S. Bioorg. Med. Chem. 2010, 18, 8235-8242. [CrossRef] [PubMed]

29. Chan, D.S.-H.; Yang, H.; Kwan, M.H.-T.; Cheng, Z.; Lee, P.; Bai, L.-P.; Jiang, Z.-H.; Wong, C.-Y.; Fong, W.-F.; Leung, C.-H.; et al. Structure-based optimization of FDA-approved drug methylene blue as a c-myc G-quadruplex DNA stabilizer. Biochimie 2011, 93, 1055-1064. [CrossRef] [PubMed]

30. Zhang, Z.; Wang, Q.; Wu, Q.; Hu, X.Y.; Wang, C.X.; Mei, W.J.; Tao, Y.Y.; Wu, W.L.; Zheng, W. Preparation and Characterization of Phenanthroimidazole-based Derivatives with Ether Linkage at N1-Phenyl. J. Chem. Chin. Univ. 2014, 35, 1691-1696.

31. Chen, T.; Wong, Y.S. Selenocystine induces reactive oxygen species-mediated apoptosis in human cancer cells. Biomed. Pharmacother. 2009, 63, 105-113. [CrossRef] [PubMed]

32. Liu, Z.-L.; Mao, J.-H.; Peng, A.-F.; Yin, Q.-S.; Zhou, Y.; Long, X.-H.; Huang, S.-H. Inhibition of fatty acid synthase suppresses osteosarcoma cell invasion, and migration via downregulation of the PI3K/Akt signaling pathway in vitro. Mol. Med. Rep. 2013, 7, 608-612. [CrossRef] [PubMed]

33. Lu, X.-H.; Shi, S.; Yao, J.-L.; Gao, X.; Huang, H.-L.; Yao, T.-M. Two structurally analogous ruthenium complexes as naked-eye and reversible molecular "light switch" for G-quadruplex DNA. J. Inorg. Biochem. 2014, 140, 64-71. [CrossRef] [PubMed]

34. Kitchen, D.-B.; Decornez, H.; Furr, J.-R.; Bajorath, J. Docking and scoring in virtual screening for drug discovery: Methods and applications. Nat. Rev. Drug Discov. 2004, 3, 935-949. [CrossRef] [PubMed]

Sample Availability: Samples of the compounds 1-4 are available from the authors. 